\title{
$\mathrm{D}$ i $v$ e r s o s
}

\section{A proposito do premio "Rodrigues Alves"}

Publicamos, a seguir, o discurso proferido pelo Professor CARDOZO DE MELLO NETO, em 15 de março de 1932, na ocasião da entrega desse premio aos bachareis Oswaldo Aranha Bandeira de Mello, Raphael Monteiro de Barros e Carlos Alberto de Carvalho Pinto, que foram os alunos que mais se destinguiram nas turmas 1926-1930 e 1927-1931.

“E' a primeira vês que o premio "Rodrigues Alves", instituido por iniciativa do Centro Academico "XI de Agosto", é entregue, em sessão publica da Congregação dos Professores, áqueles que 0 mereceram por haverem alcançado o maior numero de notas distintas, em cada quinquenio de estudos. Justo é, pois que aos nomes dos premiados de hoje, srs. bacharelis Raphael de Blarros Monteiro e Oswaldo Aranha Bandeira de Mello, que "ex aequo" a ele fizeram jús no periodo de 1926 a 1930, e sr. bacharel Carlos Alberto de Carvalho Pinto, "primus inter pares" da turma de 1927 a 1931, junte a Congregação a dos que, anteriormente, se haviam distinguido mo amor ao estudo, demionstrando o maximo aproveitamento escolar.

Ressgata, destarte, esta Casa uma divida para com os premiados; solve-ra aclamando seus nomes neste augusto recinto, o que por certo constitue a essencia do premio ás virtudes e qualidades do estudante, não a pecunia que naquele se contém.

Resgata uma divida, e cumpre integralmente a vontade do Centro instituidor, qual a de incentivar a aplicação dos estudantes que, por bem merecer a recompensa publica, levarão ao apice seus esforços durante o curso, com proveito proprio e lustre sempre crescente da nobre classe dos homens do Direlito, que, ha um seculo, 
vêm preponderando, por sua superior mentalidade e entranhado amôr lao Brasil, na formação da historia patria.

Os nomes que devem ser, assim, lembriados são os dos srs: Gabriel José Rodrigues de Rezende Filho; Gontran Reis; Lourenço de Freitas Camargo, Orlando Fonsca e Braz de Sousa Arrudla; Felix Peral Rangel e Odilon Guimarães Bueno; Raul Affonso Machado; Francisco Oscar Penteado Stevenson; Paulo Grassi' Bonilha e Paulo de Mesquita; Waldomiro Lobo de Costa; João Pereira Monteiro Jor. e José Pinto Antunes; e Pedro Antonio de Oliveira Ribeiro Neto.

Meus jovens colegas,

O premlio que óra vos é conferido, traz o nome de - Rodrigues Alves. Tomai-o por paradigma, tanto na vida publica quanto na do vasso lar; e podereis caminhar serenos, firmes e resolutos, pela existencia afóra.

Vêde-o, modesto filho de Guaratinguetá, desconhecido num Colegio da Côrte que, por essa epoca, reunia os filhos dos grandes do 2. Imperio - primeiro estudante do Colegio Pedro II. E' Joaquim Nabuco, seu condiscipulo, quem o testemunha numa passagem da "Minha Formação": "Filho do presidente do Conselho, foi para mim uma vibração de amôr proprio mais forte do que teria sido, imagino, a do primeiro premio que o nosso camarada Rodrigues Alves tirava todos os anos".

Vêde-o, a seguir, nesta Academia, na primeira linha /duma turma memoravel: - a de Ruy Barbosa e Castro Alves, de Joaquim Nabuco e Aureliano Coutinho, de Sancho de Barros Pimentel e Affonso Penna.

Por essa epoca, aqui se fazia politica, a verdadeira politica, não aquela que, mais tarde, se entendeu chamar a "politica academica", isto é, a divisão dos estudantes em grupos, sem qualquer diferenciação de ideal ou de tendencias, mas a politica dos tradícionais partidos do Imperio.

A maior honra estava no logar de redator-chefe da "Imprensa Academica", ocupado por um bacharelando. Conservador, Rodrigues Alves disputou-o a Affonso Penna, liberal. Empataram. E o jornal teve esse $a$ no, por exceção, dois redatores-chefes.

Fóra da Aicademia, era ele um dos mais assiduos colaboradores da "Opinião Conservadora", orgão do Partido. Tanto ahi se distinguiu, que João Mendes, o velho, que dirigia então a imprensa do Partido, entendeu do seu dever apresentá-lo ao publico da provincia como "digno do melhor apreço pelo seu carater sizudo, inteligencia cultivada e ideias sãs". João Mendes, com sua acuidade, descobrira no joven bacharel, o futuro homem publico. 
Eli-lo em Guaratinguetá, sua terra natal. Começa, então, para só terminar com a morte, a vida politica de Rodrigues Alves.

São 50 anos de dedicação ininterrupta ao interesse publico. Durante o Imperio: deputado provincial, deputado geral, presidente da provincia de S. Paulo, conselheiro honorario do Estado, tudo antes dos 40 anos. Na Republica: deputado á Constituinte, Ministro da Fazenda de Floriano e de Prudente, presidente de S. Paulo e, a seguir, presidente da Republica, no famoso quatrienio de 1902 a 1906; outra vês, presidente de S. Paulo, e logo após de novo eleito presidente da Republica, não tendo podido assumir o cargo por motivo da grave enfermidade, de que veiu a falecer.

Sem exagero, com a historia politica da Republica se entrelaça a vida publica de Rodrigues Alves. Em outras circunstancias quenão as atuais, bastára pronunciar seu nome, para que todos quantos vivem a vida do Brasil recordassem sua obra imperecivel. Recordasselm-na e procurassem imitá-la.

Hoje, porém, quando de tudo se duvida, num momento em que se faz praça de desconhecer e amesquinhar os serviços que ao Brasil prestaram seus maiores filhos - epoca de insânia, em que se pretende construir um Brasil novo, sem consciencia juridica e sem respeito á vontade soberana do povo; hoje que se proclama a fallencia da politica como arte da direção do Estado, e se cuida substituí-la por qualquer corpo de doutrinas abstrusas, mal compreendidas, e ainda peior apllicadas; num momento historico, em que são afastados da direção do Estado os homens do Direito, de que aquele é o guarda; é preciso voltarmo-nos para os nossos maiores e procurar seguir-lhes a róta, sem desfalecimentos, nem hesitações, a beneficio do Brasil, restituindo á terra patria, em sacrificios de toda a ordem, aquilo que ela nos proporcionou em beleza, em dignidade e em magnitude.

Rodrigues Alves é um desse numes tutellares.

Seu nome precisa ser recordado no cáos do Brasil atual.

Admiremos sua visão de estadista, - aquela que, contrariando a opinião de sua provincia, fê-lo opôr-se á primeira valorização do café - passo inicial, em falso, do qual têm resultado todos os maleficios para a economia paulista; - aquela que, no governo da Republica, soube descobrir, a um tempo, Rio Branco e Oswaldo Cruz, Pereira Passos e Lauro Müller, com eles realizando a formidavel obra de integração do Brasil nos limites de suas fronteiras, e do Rio de Janeiro, na civilisação, pela extinção da febre amarela.

Saibamos, imitando-o, resistir á desordem e ao motim militar, como ele fez, em 14 de novembro, ficando, serenamente, "no seu logar".

Tomando-o por modelo, saibamos transigir curvando-nos á opinião nacional, como ele o fez no càso de sua sucessão. 
Como ele, tenhamos o culto da dignidade, da dignidade das. palavras, dos proprios gestos, das atitudes - esse "quid" inconfundivel que, ao mesmo tempo, infunde confiança e afasta a familiaridade.

Como ele, finalmente, (é de Ruy o julgamento): "ponhamos a Patria acima das localidades, a Republica acima das facções, a Constituição acima dos individuos, e acima dos cortezãos a opinião nacional".

Um dia houve, talvez o mais belo da vida de Rodrigues Alves, em que, ameaçado S. Paulo na sua autonomia, as correntes politicas sacrificando velhas e conhecidas divergencias, se congregaram todas, e foram buscar no retiro de Guaratinguetá o homem, unico considerado capaz de, por seu prestigio, impedir o atentado. 0 ultimo dos grandes presidentes paulistas volta então a assumir o governo de seu Estado. E a sua só presença restabelece a confiança e faz voltar a paz.

Os milagres não se reproduzem: Rodrigues Alves só vive hoje no coração dos filhos, e na memoria dos que reverenciam o passado.

Mas, a historia se repete.

Hoje, como ontem, os paulistas se encontram unidos em torno da defesa da autonomia de Piratininga.

Hoje, como ontem, velam por nós os numes tutelares da terra que só quer ser grande e prospera, para poder repartir-se com seus irmãos". 